\title{
Financial Literacy in Education Process: Literature Study
}

Burku Özdemir ${ }^{1}$

\section{ARTICLE INFO}

Article History:

Received 01.11.2020

Received in revised form

18.08.2021

Accepted

Available online 01.07.2022

\begin{abstract}
One of the factors affecting the quality of life of individuals is financial decisions. Every activity that individuals do to meet their needs is within the scope of finance. For this reason, Financial literacy is a concept that closely concerns every individual living in society. Financial literacy includes individuals to have information about financial issues and to make the right investment and consumption decisions. Accordingly, having a financial literacy education at early age and to sustain it throughout life. Regarding this importance, the aim of the article is to compile the studies on the importance of financial literacy education and to provide theoretical resources to the literature. For this purpose, this review article consists of three parts. In the first part, the definition and content of the concept of financial literacy are mentioned. In the second part, the place and importance of financial literacy in education, its benefits to the general public and students, and the necessity of financial literacy education are mentioned. In the last part, it is mentioned about the projects that have been realized and are being realized in the field of financial literacy in Turkey.
\end{abstract}

CTUARA Journal. All rights reserved

Keywords:

Financial literacy, financial literacy education, the importance of financial literacy, financial literacy project

\section{INTRODUCTION}

In the twenty-first century, there have been economic events that have seriously affected the whole world. Considering these effects, it is seen that the economy is a part of life and it is a very important issue that students should be given skills, attitudes and awareness on finance-related issues through education (Çetin, 2015). Educational institutions, which are an important means in providing the trained qualified manpower of the country, also meet the needs of the society and the individual. For this reason, investment in education is important in term of socio-economic development of the country, as in many aspects.In this respect, it is necessary to educate individuals from all segments of the society in order to ensure the economic development of the country. Putting new rules that are suitable for the purpose, which will be developed through education, helps to accelerate economic development (Hoşgörür, 2005).

The fact that people face the concept of finance in every activity they do throughout their lives makes it necessary to have information about their own financial situation. Therefore, the fact that individuals who make up the society have received literacy training on economics and finance is an effective factor in acquiring economic and financial management skills (Bayram, 2010). It is very important that financial decisions are made early and maintained throughout life. This makes it necessary for the concept of financial literacy to be included in the education system. Hogarth (2002) states that financial literacy is on extremely skill because financially equipped, well-educated consumers make better financial decisions, have security and welfare that increases their economic situation, contribute to the strong formation of societies and support economic development (Act., Johnson and Lewis, 2009).

When the prominent practices regarding some countries are examined by making use of the data obtained as a result of the OECD Financial Education: Trends and Recent Developments Report; It has been revealed that the financial literacy levels of Estonia, which has seen a continuous increase in PISA in recent years, are at an advanced level. Estonia included content on financial skills in its national curriculum for the first time in 1996. Financial approaches, which were revised in 2010, were embedded in the contents at the courses at primary and secondary school levels. In addition, financial institutions and organizations in Estonia, especially banks, have a very important role in the implementation of national strategies (OECD, 2016).

${ }^{1}$ ozdemirburku@gmail.com, orcid.org/0000-0001-9799-186 
Similarly, in the 2016 OECD report, financial literacy education in Ireland is embedded in secondary school mathematics courses, while financial literacy is supported by elective courses called home economics. As in England, Scotland, Northern and Southern Ireland, financial literacy trainings have been put into practice in different forms and in different processes in the United States. After 2014, England started to provide financial literacy education within the scope of mathematics and citizenship courses by placing it in the country's education program (OECD, 2016).

In Turkey, some of the works envisaged in the first national strategy financial action plan prepared by the Capital Markets Board in 2014 are as follows (CMB, 2014).

1) Organizing a "Financial Education Summit" every year with the participation of individuals and institutions engaged in financial education activities.

2) Development of basic finance topics in curriculum and non-formal education programs suitable for primary and secondary education level.

3) Carrying out projects to attract students' interest in financial matters.

4) Informing and educating teachers and education administrators on financial issues.

When all these practices are examined, it is seen that financial literacy education and skills have started to be given importance throughout the world. In this context, financial literacy lessons, which are needed by all age groups, have been tried to be included in formal education in order to increase the financial literacy levels of children starting from a young age (Ontario, 2010). Thus, since individuals have sufficient knowledge on financial issues, they will adapt quickly to the changing and developing conditions over the years and will not have difficulty in planning their future. Learning to overcame economic events for young individuals is among the main objectives of citizenship education (Adalar, 2019). Individuals need to have financial literacy to successfully execute financial processes and manage money. Thus, individuals will be aware of their basic needs and will be able to predict their future financial burdens. In other words, an individual with financial literacy gains the ability to think in multiple ways to reach his financial goal (Öztürk \& Demir, 2015). Financial literacy is accepted as a basic life skill that should be acquired at an early age by the "Program for International Student Assessment (PISA)" (OECD, 2014). Financial management is a situation that will not end throughout life. Budget, savings, spending, investment, etc. issues are important for individuals in every period. Finance is not just a field that concerns professionals, it concerns individuals from all walks of life, including children. Young people's interest in and understanding of financial issues will make it easier for them to easily manage and find solutions to financial crises that may happen to them in the future. In addition, young people with high financial literacy will be able to manage their lives consciously. Developing financial education at an early age enables individuals to reach their dreams and plan their future investments at a micro scale, while at a macro scale it ensures that all segments of the society have regular access to the financial system and underlines balanced and sustainable growth.

The ability to make the right financial decision is a skill that should be acquired at an early age. In this context, raising conscious individuals and making the right financial decisions are beneficial both for individuals and for the economic development of the country. With this study, it is aimed to compile the studies on financial literacy, which has individual and social benefits. In addition, the deficiencies in the literature regarding the concept of financial literacy, which is accepted as a basic skill by PISA and highlighted as an important skill in the MEB 2023 vision document, will be evaluated and improved.

\section{METHOD}

This research was designed as a literature-based review study. In this respect, after examining the related studies, information was reported with descriptive analysis (Yıldırım \& Şimşek, 2006). In this way, it has been attempted to form a review synthesis (Baumeister \& Leary, 1997). Compilation studies are articles in which the information obtained by different methods and ways related to the subject is compiled (Baştuğ, 2021). In this respect, firstly, a literature review was conducted on the subject. In the second stage, it was aimed to examine the general situation of financial literacy education by evaluating, interpreting and synthesizing the literature.

\section{Concept of Financial Literacy}

Recent developments in financial markets, population, economy and administrative changes all emphasize the importance of financial education. The increase in the world population, due to the inadequacy of natural resources; among the economic and social policies of all countries when used as a term. It is used as financial literacy in Australia and the United States and in some countries, while it is used as financial ability 
in Canada and the UK (Remund, 2010). While some organizations and authors use the concept of financial literacy, they may use economy literacy instead of financial literacy (Kaderli, Y. Gümüş, U.T. and Eskici, Y. 2016). In its simplest definition, financial literacy is the ability of individuals to have financial knowledge, to use financial resources and money in the most effective way, and to maintain this ability throughout their life.

According to the Organization for Economic Cooperation and Development (OECD), which makes important researches on the concept, financial literacy is; it is defined as the process of gaining knowledge and ideas about financial terms and risks and developing skills to apply this information in order to increase the welfare level of individuals and society, ensure their participation in economic life, and make the right decisions in financial understanding (OECD, 2013).

The earliest known use of the concept of financial literacy was in the report prepared by NatWest Bank for National Education Foundation Research in 1992. In the report, financial literacy is defined as the ability of individuals to make conscious and effective decisions in the use and management of money (Lee, 2012).

According to Remund (2010), financial literacy is "the ability and self-confidence of individuals to manage their finances in relation to short-term decision-making and long term financial planning, according to their changing life and economic conditions". According to Atkinson and Messy (2012), "financial literacy is the combination of individuals' making the right decisions, managing their finances, financial awareness, knowledge, skills and behaviors". According to Robb, Babiarz, and Woodyard (2012), financial literacy is "the ability of individuals to understand and effectively use basic information about finance".

Starting from the common point of the definitions, in order for people to be financially literate, they need to have awareness, knowledge, skills, attitudes and behaviors about finance. The 3 basic elements required for financial literacy are demonstrated on Table 1.

Table 1: The 3 Basic Elements of Financial Literacy (Suryadi, 2019)

Financial Knowledge

Financial Behavior
1. Fundamentals of finance

2. Money management

3. Credit and savings

4. Savings and investment

5. Risk

1. Management thinking pattern money well

2. Attitude of satisfaction shop

3. Owning comfort money

4. Attitude doesn't feel enough towards income

5. Attitude doesn't want to spend money

6. Independence of management money

1. Budgeting

2. Money savings and patterns shopping

3. Savings and investment

4. Payment of obligations

When the 3 basic elements are examined, we can say that the dimension of financial behavior is about individuals giving up their wishes and changing their habits.

The Place and Importance of Financial Literacy in Education

In recent years, the diversity of financial products and services has been increasing. This situation creates the need to increase the financial literacy level of the society. Today, the existence of a curriculum for the development of financial literacy in the basic education process, starting from pre-school, draws attention in the education systems of many developed countries. In this connection, it has emerged that individual financing should be included in the education processes of all students in the society. It has been demonstrated in many studies that the introduction of financial education in the school curriculum causes positive behavior changes (İçke, 2017). In a study conducted by Danes in 2004, it was measured that high school students who received financial literacy education had a significant and positive effect on their spending habits (Danes, 2004). 
Increasing the level of financial literacy is a necessary factor for the consumer to make the right choices between different products in financial services, which are increasingly complex (Hathaway and Khatiwa, 2008). The way to increase the level of financial literacy in education. Thanks to financial education, individuals gain knowledge, skills, attitudes and behaviors that enable them to make rational decisions about money management (Global Education Program, 2009). Financial literacy education is necessary for every individual in the society to make informed choices. Young people need broad knowledge, skills and attitudes about financial literacy in order to be better prepared for life.

Financial literacy to students (Ağırman and Akyol, 2019):

1) Detailed thinking in financial choices (Rational decision-making in consumer behavior is valid in daily decisions from buying food to large investments).

2) Basic money management.

3) Developing their own perspective on issues such as interest rates, mortgage rules, national economy and global economy.

4) Being on informed responsible citizen who can decide where and how to spend his money.

5) Ensuring life-long financial stability.

6) It will help to understand the effects of economic choices on the world they live in.

Financial literacy is an important concept for countries to achieve a better economic welfare. With financial literacy education, people's awareness of financial issues, correct use of financial tools, making conscious and effective decisions regarding the use and management money, contributing to the country is economy on a macro scale, and financial stability are pursued. With financial education, individuals develop the ability to comprehend and evaluate information about budget, savings, investment instruments. This type of education will effect an individual's current and future well-being. When it comes to mind that the resources that have been provided for years by making the necessary savings or by some borrowing, these resources will disappear immediately with the wrong investment, it is seen how important the financial trainings given are in determining the level of welfare that people will continue throughout their lives (Özcam, 2006).

The Central Bank of the Republic of Turkey, in its bulletin published in 2015, explained the necessity of financial education as follows:

"1. Transactions in financial markets, which are becoming more and more common in daily life, require a certain level of financial knowledge, sufficient risk analysis and awareness.

2. The diversity and complexity of financial services and products is increasing day by day. While this increases the product range, it also makes it difficult to get enough information about new products.

3. The existing global economic structure, consumption causes these trends to gain strength day by day, while the share of borrowing in the financing of this trend is increasing.

4. With the increasing share of the private sector in the pension system and the increase in life expectancy, individuals have to make a more detailed assessment of their savings.

5. Studies in progress to measure financial literacy show that literacy in financial terms is at a low level.

6. Financial education contributes to financial access."

Considering the problems that may be experienced, financial education should be given from a young age and it should be a process that should continue throughout the person's whole life. In this way, individuals will have sufficient level of knowledge while dealing with daily financial problems and transactions that will increase their level of financial literacy, and will be able to act with confidence and demonstrate the ability to use financial products and services more accurately.

Projects Implemented on Financial Literacy in Turkey

In our country, projects have been carried out by different institutions for the development of financial literacy. Some of the related works have been completed and some are still in progress.

United Nations Development Program, Visa Turkey and Habitat Association came together to contribute to sustainable development by raising financial awareness among young people. "I Can Manage My Money Project" is defined as a financial literacy and budget management project for young people. With the project implemented on December 1, 2009, a first in Turkey, the public, private sector and civil society were brought together within the scope of financial awareness. The target of the project is young people between the ages of 15-30. It aims to provide young people with education that properly supports their budgets and financial services. (Habitat, 2009). In order to increase financial literacy in terms of increasing social welfare and financial awareness through financial education, the Central Bank of the Republic of Turkey and the Capital 
Markets Board worked together to organize an international conference on Financial Education and Financial Awareness: Challenges, Opportunities and Strategies in Istanbul between 9-11 March 2011. In addition, in March 2011, the Central Bank of the Republic of Turkey published the booklet "Access to Financial Services and Financial Education in the World and in Turkey" and distributed it nationwide (TCMB, 2011).

Financial Literacy and Inclusion Association (FODER) was established in 2012 under the leadership of Özlem DENIZMEN. Collaborating with government, private sector and non-governmental organizations in order to create financial literacy, financial access awareness and opportunities for individuals across the country; was established to raise awareness, support education, research and practices, and make policymaking studies. The ultimate goal of the association is to create an ecosystem for a financially literate Turkey. In 2014, FODER, with its volunteer trainers, reached 10 thousand 3rd, 4th and 5th grade students in 10 schools in 4 provinces throughout Turkey during the 10-17 March "Learning Money Week". The aim of the training content organized by FODER is to raise financially literate generations. In the "Secrets of the Wealthy Future" training, the topics of desire, need and expenditure were discussed and the differences between savings, aid and investment were explained. The first part of a 3-module course teaches you how to reach your short and long-term savings goals and how to achieve them by working in a planned manner. The final module tries to make a link between education and real life by involving children's education, creating a dialogue and strengthening expression. (FODER, 2014).

In March 2014, a cooperation protocol on financial education was signed between the Capital Markets Board and the Ministry of National Education, General Directorate of Innovation and Education Technologies. In this context, content that will enable children and young people between the ages of 6-18 and teachers to develop and apply their basic knowledge on financial issues, various visual, audio, etc. Digital education contents with multimedia elements were published in the Education Information Network (EBA) and EBA Market of the Ministry of National Education within the scope of the Fatih Project. In addition, it has been decided that teachers and students in all schools affiliated to the Ministry of National Education can benefit from these contents free of charge (SPK, 2014). Organized by Child \& Youth Finance International (CYFI), which was established to raise financial awareness for children and young people, II. CYFI Summit and Award Ceremony was held at Hilton Istanbul between 7 - 9 May 2013. The first CYFI summit was held in Amsterdam in 2012 with the participation of 364 public and private sector representatives from 83 countries and 70 children and young people from 40 countries on "Financial Access" and "Financial Education for Children and Youth". (SPK, 2013). Programs, trainings, promotions, etc. to increase awareness and financial literacy on the stock market and capital markets in cooperation with Borsa İstanbul and Anadolu University. A protocol was signed with the aim of realizing the activities. In this direction, as of the 2013 Spring semester, Basic Level Financial Literacy and Advanced Financial Literacy programs have been launched within the scope of Anadolu University e-certificate program (Bayram, 2015).

In the economics module within the scope of the Family Education Program conducted by the Ministry of Family and Social Policies, General Directorate of Family and Social Services in 2009, the aim of financial literacy is that families can determine their needs at different times, control their expenditures, realize financial products and tools in line with their needs, possible problems and taking precautions against excessive borrowing, being prepared for economic bottlenecks and crisis situations (Ministry of Family and Social Policies, 2013). Within the scope of the Istanbul International Financial Center project and the Medium Term Program covering the period 2010-2012, the IFC-Istanbul Project was put into practice in line with the Strategy and Action Plan. The aim of this project includes the measures to be taken to make our country a global and regional financial center (İFM, 2010).

\section{Conclusion and Discussion}

In this study, studies on financial literacy were examined. It has been concluded that financial literacy, which is accepted as a basic life skill, is important individually and socially. As a result of this, it has been concluded that it should be integrated into the education system at an early age. This importance is supported by similar results in the literature.

In their study, Bernheim et al. (2001) stated that the majority of their states have adopted consumer education policies and that it is compulsory for high school students to receive education on financial issues. As a result of the research, it was observed that the students who received financial literacy education in high school save money and increase their income levels later in life. Peng (2008) evaluated the personal financial education of high school students in high school in his study. Looking at the results, a positive effect was 
observed between course duration and financial literacy. He stated that the most effective way to increase financial literacy education is to be encouraged to work closely with government institutions. In a study conducted by Sabri et al. (2010) among university students in Malaysia, it was concluded that university students with high levels of financial literacy experience fewer financial problems and exhibit positive attitudes towards saving behavior.

Saraç (2014) examined how university students make financial decisions, their financial literacy levels and how this level can be increased. As a result of the research, it was stated that the financial literacy levels of the students are low, and that financial literacy education should be given starting from primary school to university in order to increase the level of financial literacy throughout the society. As a result, financial literacy concerns individuals from all age groups in the society. Education at an early age plays a key role both in planning the future of individuals and in increasing the welfare level of the society.

When the studies are examined, although it is stated that the concept of financial literacy is important, studies on the related field are limited. Therefore, more work can be done on the subject. Awareness can be created throughout the country due to the high benefits for both individuals and society. Relevant content can be edited to integrate it into educational levels. Financial literacy can be added to the curriculum of the relevant courses in line with the determined objectives. The importance of the subject can be conveyed to students by presenting it as an elective course in schools. Compliance and activities related to the subject can be created for each level of education. A program can be developed for all levels of financial literacy in accordance with the culture of the society.

\section{REFERENCES}

Adalar, H. (2019). Sosyal bilgiler öğretmen ĕğitiminde finansal okuryazarlık ve öğretimi: Bir model önerisi. (Doktora Tezi, Gazi Üniversitesi, Ankara)

Ağırman, E., \& Akyol, Ş. (2019). Finansal okuryazarlık IïBF öğrencileri üzerine bir araştırma. Bursa, Ekin Yayınları.

Aile ve Sosyal Politikalar Bakanlığ1 (2013). Aile eğitim programı, program kitabı. İstanbul.

Atkinson, A. \& Messy, F. (2012) Measuring financial literacy: Results of the oecd/1nternational network on financial education (INFE) pilot study. OECD Working Papers on Finance, Insurance and Private Pensions, No. 15, OECD Publishing.

Bayram, S.S. (2010). Finansal okuryazarlı ve para yönetimi davranışları: Anadolu üniversitesi öğrencileri üzerine uygulama. (Yüksek Lisans Tez, Anadolu Üniversitesi, Eskişehir).

Baumeister, R. F.,\& Leary, M. R. (1997). Writing narrative literature reviews. Review of General Psychology, $1(3), 311-320$.

Baştuğ, S., \& Aydın, S. C. (2021). Denizcilik eğitiminde oyunlaştırma üzerine derleme türünde literatür çalışması. Deniz Taşımacılı̆̆ı ve Lojistiğ i Dergisi, 2(1), 28-35.

Çetin, O. (2015). Küreselleşmenin eğitimin farklı boyutlarına üzerindeki etkisi. Çă̆daş Yönetim Bilimleri Dergisi,2 (1),75-93.

Danes, S. M., \& Haberman, H. (2004), “Evaluation of the NEFE high school financial planning program, 20032004". St. Paul, MN: University of Minnesota, Family Social Science Department.

Global Education Program (2009)" Financial literacy, financial education, financial capabilities: Are they different?" Financial Education Update 3, (2),1.

Hathaway, I., \& Khatiwada, S. (2008). Do financial education programs work? Working paper 08-03. Federal Reserve Bank of Cleveland.

Hoşgörür, V. \& Gezgin. G. (2005). Ekonomik ve sosyal kalkınmada eğitim. Van Yüzüncü Yıl Üniversitesi Eğitim Fakültesi Dergisi.2(1).

İçke, B.(2017). Finansal okuryazarlık finansın dilinden anlıyor muyuz? İstanbul: Beta Basım Yayım Dağıtım.

Johnson, C.A.\& Lewis, A.R. (2009). Consumer economics and family resources: importance of financial literacy. Journal of Family Consumer Sciences Education, 27.

Kaderli, Y., Gümüş, U.T. \& Eskici, Y. (2016). Seçilmiş ülke örnekleriyle finansal okuryazarlığın önemi ve tasarruflar üzerindeki etkileri. Leges Hukuk Dergisi, 7(73-75), 85-122.

Lee, N. (2012). What is financial literacy, and does financial literacy education achieve its objectives? Evidence from banks, government agencies and financial literacy educators in England. In the Proceedings of 2012 Academy of Financial Services Annual Conference at San Antonio, USA E (Vol. 4). 
OECD (2014). PISA 2012 Results. students and money: Financial literacy skills for the 21st century (Volume VI), PISA, OECD Publishing.

OECD. (2016). Financial education in europe trends and recent developments financial. OECD Publishing

Ontario (2010). A sound investment financial literacy education in Ontario schools. Report of the Working Group on Financial Literacy. Ministry of Education Ontario Working Group on Financial Literacy, Toronto: Ministry of Education Ontario.

Öztürk, E., \& Demir, Y. (2015). Finansal okuryazarlık ve para yönetimi: Süleyman Demirel Üniversitesi akademik personel üzerine bir uygulama. Journal of Accounting E Finance, (68).

Peng,T. M.(2008).Evaluating mandated personal finance education in high schools. (Master's Thesis, The Ohio State University, Amerika).

Remund, D. L. (2010). Financial limteracy explicated: The case for a clearer definition in an increasingly complex economy. The Journal of Consumer Affairs, 44(2), 279.

Robb, C. A., Babiarz, P., \& Woodyard, A. (2012). The demand for financial professionals advice: The role of financial knowledge, Satisfaction and Confidence. Financial Services Review, 21(4), 291-305.

Sabri, M.F.-Macdonald, M. (2010). Savings behavior and financial problems among college students: The role of financial literacy in malaysia. Cross-Cultural Communication, 6(3), 103-110.

Saraç, E. (2014). Finansal okuryazarlı ve Dumlupınar Üniversitesi öğrencilerinin finansal okuryazarlı düzeylerinin ölçülmesi üzerine bir araştırma (Yüksek Lisans Tezi, Dumlupınar Üniversitesi, Kütahya).

Sermaye Piyasası Kurulu (SPK). (2014). Finansal erişim, finansal eğitim, finansal tüketicinin korunması stratejisi ve eylem planları. Ankara.

Türkiye Cumhuriyeti Merkez Bankası (TCMB). (2015). Bülten. Sayı 37.

Yıldırım, A. \& Şimşek, H. (2006). Sosyal bilimlerde nitel araştırma yöntemleri. Ankara: Seçkin Yayıncılık. 